\title{
ACUTE TOXICITY AND VASCULAR PROPERTIES OF SEED OF PARKIA BIGLOBOSA (JACQ) R. BR GIFT (MIMOSACEAE) ON RAT AORTA.
}

\author{
Sylvin Ouédraogo ${ }^{a *}$, Noya Soméa , Sounkalo Ouattara ${ }^{c}$ Félix B. Kini $^{\mathrm{a}}$, Aristide Traore ${ }^{\mathrm{a}}$, Bernard \\ Bucher $^{\mathrm{b}}$ and I.Pierre Guissou ${ }^{\text {ac }}$
}

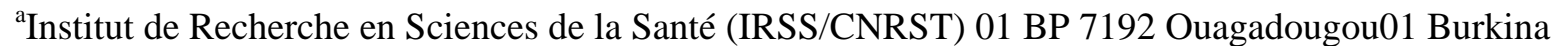
Faso. ${ }^{b}$ UMR 7213 C.N.R.S. Laboratoire de Biophotonique et Pharmacologie, 74 route du Rhin, BP 60024 ; 67401 ILLKIRCH CEDEX

${ }^{\mathrm{C}}$ Université de Ouagadougou BP 7047 (Burkina Faso)

*E-mail: osylvin@yahoo.fr

\begin{abstract}
The authors report here the results of study on Parkia biglobosa seeds used in Burkina Faso for arterial hypertension treatment. Investigations were done on acute toxicity and vascular properties of fermented and roasted seeds. Acute toxicity test using mice, revealed by the intraperitoneal route a lethal dose $50\left(\mathrm{LD}_{50}\right)$ of $1800 \mathrm{mg} / \mathrm{kg}$ and $1600 \mathrm{mg} / \mathrm{kg}$ of body weight for aqueous extract from roasted and fermented seeds respectively. According to the scale of Hodge and Sterner and that of the World Health Organization, such drugs would be classified lightly toxic. Oral administration (up to 3000 $\mathrm{mg} / \mathrm{kg}$ ) did not induce any death of animal. For the vascular properties, the effects of these products were tested on the aorta isolated from rats. The cumulative administration of extract from roasted and fermented seeds $(0.1-10 \mathrm{mg} / \mathrm{mL})$ in an organ bath induced a concentration-dependent relaxation of the aorta pre contracted by phenylephrine, with or without functional endothelium. The extracts $(10 \mathrm{mg} / \mathrm{mL})$ inhibited for $100 \%$ the contraction induced by phenylephrine. The EC 50 values in presence and absence of endothelium were respectively of $5.37 \pm 0.12$ and $4.19 \pm 1.02 \mathrm{mg} / \mathrm{mL}$ for fermented seeds; for roasted seeds these values were respectively, $5.39 \pm 1.12$ and $5.93 \pm 0.95 \mathrm{mg} / \mathrm{mL}$. Nevertheless, low concentration of roasted seeds (1-4 mg/mL) induced endothelium-dependent relaxation and this effect was inhibited by indomethacin $\left(10^{-5} \mathrm{M}\right)$, and not by L-NAME $\left(310^{-4} \mathrm{M}\right)$. These experimental results revealed a vasorelaxant effect of $P$. biglobosa seeds. $P$. biglobosa seems to act directly on the smooth muscle and via endothelium involving the generation of vasodilatating prostaglandins. This vasodilator effect would be in favor of an anti hypertensive property of $P$. biglobosa seeds.
\end{abstract}

Key words: Acute toxicity; vasodilator; endothelium; Parkia biglobosa.

\section{Introduction}

Arterial hypertension constitutes a cardiovascular risk characterized by the increase in the cerebro-vascular, coronary, cardiac and renal accidents (Du Caillar et al., 1995; Pechere et al., 1996). It is currently the common cardiovascular disease in Black Africa with about 10 to 15\% in the adult population (Bertrand et al., 1995; Olatunbosun et al., 2000) including a strong prevalence in urban environment (Cooper et al., 1997; Van Rooyen et al., 2000).

In Burkina Faso, Niakara et al., (2003) revealed a prevalence of $23 \%$ for arterial hypertension in the population with a strong rate in urban environment. Hospital mortality due to this pathology is estimated at 20.80\% (Sermé et al., 1991; Tougma, 2002). This rate remains higher than the African hospital average in general. The treatment of the HTA in modern medicine is expensive and often difficult of access for the African popular mass in general hence an interest to traditional medicine.

Our unpublished data revealed that fifty-four (54) species belonging to twenty seven (27) families of plants were used by Mossi and Dagara people in Burkina Faso for hypertension management. P. biglobosa is among the most cited one and according to these investigations, Mossi people use fermented seed, while Dagara people use fermented and roasted one for the management of hypertension. Previous investigations show potent antihypertensive properties of $P$. biglobosa leaves, bark, and seed (Assane et al 1993, Nacoulma, 1996; Kane et al 2009, Tokoudagba 2010). This work aimed to evaluate the vasorelaxant properties of fermented seeds commonly used by populations and roasted seeds.

\section{Experimental}

Plant and extract

P. biglobosa seeds were collected in the southern region of Burkina Faso (savanna zone) in April 2007 (dry season). Plant materials were verified to be identical samples at the specimen herbarium of the National Herbarium, National Centre for Scientific and Technological Research (Burkina Faso). A voucher specimen (WINKOUN D.H. N669) was previously deposited at this herbarium. Vegetable material consisted of roasted and fermented seeds from $P$ biglobosa. For the roasted one, seeds were peeled and the almonds obtained were roasted and then pulverized. For fermented seeds, they were bought on the market in the same region. They were also pulverized. The aqueous extract was prepared as follows: the dried powders $(150 \mathrm{~g})$ were extracted in $750 \mathrm{~mL}$ of distilled water under mechanical agitation during 24 hrs. Each extract was filtered and centrifuged. Part of the filtrate obtained was reserved for phytochemical studies. The other part was then frozen and lyophilized for pharmacological and toxicological tests. 


\section{Phytochemical screening:}

Qualitative phytochemical analysis was made according to the reactions of characterization based on Ciulei, (1982) method. For chemical groups better characterization, it was necessary to make aqueous extract acid hydrolysis. After hydrolysis, the lipophilic substances were extracted by using chloride methylen $\left(\mathrm{H}_{2} \mathrm{CL}_{2}\right)$. This organic phase is supposed to contain the chemical groups having a great affinity for solvent. It acts on aglycon flavonoïdic, sterolic, triterpenic, coumarinic and anthraquinonic groups. The residual aqueous extract would contain the polar components which are: saponosid, tanins, alkaloids and reducing components.

\section{Acute toxicity study}

Three months old NMRI mice, weighting between 20 and 40 g were put on a diet for 24 hrs; they were set out in batch of six mice. Extracts were administrated by oral and intra peritoneal routes. The pilot mice receiving solvent (distilled water). The doses of extract administered were: 750, 1250, 1500, 2000, 2500 and $3000 \mathrm{mg} / \mathrm{kg}$ of body weight for each group. Animals once treated were observed during the two hrs which follow extracts administration and then they were fed. They were then observed after $24 \mathrm{~h}, 48 \mathrm{~h}$ and $72 \mathrm{~h}$. Animal's intoxication symptoms were noted. The mice that died in each batch were counted for lethal dose $\left(\mathrm{LD}_{50}\right)$ determination. Mice which did not die during $72 \mathrm{hrs}$ of observation were observed for two weeks. The $\mathrm{LD}_{50}$ was estimated according to the method described by Trevan, (1927) initial method and its various and successive modifications: Miller and Tainter, (1944); Lichtfield and Wilcoxon, (1949); Prieur et al., (1983).

\section{Aortic preparation and mounting}

Male Wistar rats (12-14 weeks old) were used. Rats were anaesthetized with pentobarbital (60 mg/kg, i.p.) mixed with 500 UI of heparin. The thoracic aorta was removed and mounted as previously described in a physiological salt solution (composition in mM: $\mathrm{NaCl} 119, \mathrm{KCl} 4.7, \mathrm{CaCl}_{2}$ 1.25, MgSO4 1.17, $\mathrm{KH}_{2} \mathrm{PO} 41.18, \mathrm{NaHCO}_{3} 25$ and glucose 11) (Andriambelson et al. 1997) maintained à $37^{\circ} \mathrm{C}$ and continuously bubbled with $95 \% \mathrm{O}_{2}-5 \% \mathrm{CO}_{2}$ mixture. Aortic rings with and without functional endothelium were pre-contracted to the same tension (i.e. 80\% of maximal response obtained in vessel with functional endothelium) with phenylephrine (Phe) $10^{-6}$ or $5 \times 10^{-8} \mathrm{M}$ respectively. When the contraction reached a steady state, increasing concentrations of extract were added cumulatively $(0.1-10 \mathrm{mg} / \mathrm{mL})$. In order to characterize the involvement of nitric oxide (NO) and cyclooxygenase (COX) products, some arteries with functional endothelium were exposed to a specific NO synthase (NOS) inhibitor, $N_{-5}^{G}$-nitro-L-arginine methyl ester (L-NAME : $3 \times 10^{-4} \mathrm{M}$ ) or to a non specific COX inhibitor, indomethacin $\left(10^{-5} \mathrm{M}\right)$, added to the bath $15 \mathrm{~min}$ before Phe. In the case of L-NAME, the concentration of Phe was adjusted in order to obtain the same level of pre-contraction as in the absence of L-NAME. This investigation was conducted following international rules and conformed to relevant ethical committee requests.

\section{Drugs and chemicals}

$\mathrm{NaCl}, \mathrm{NaHCO}_{3}, \mathrm{KCl}, \mathrm{KH}_{2} \mathrm{PO}_{4}, \mathrm{MgSO}_{4}, \mathrm{CaCl}_{2}$, glucose, Phenylephrine, Indomethacin, L-NAME and pentobarbital (Sigma Chemical Co, Grenoble, France). Indomethacin $\left(10^{-5} \mathrm{M}\right)$ was dissolved in (5\% w/v) $\mathrm{NaHCO}_{3}$.

\section{Statistical analysis}

All data were expressed as mean \pm SEM. Mean \pm SEM, concentration-response curves, and $\mathrm{EC}_{50}$ were determined by graphPad Prism version 5.00. Two ways ANOVA and Student's $t$-test were used to determine significant differences between groups. Mean values were considered significantly different when $\mathrm{P}<0.05$.

\section{Result and Discussion Phytochemical study}

Roasted and fermented seeds extraction output were $17.5 \%$ and $16.75 \%$ respectively. Chemical characterization carried out on P. Biglobosa seeds extracts made it possible to highlight the following chemical groups: triterpen and sterols are in roasted and fermented seeds. Coumarins were present only in roasted seeds (Table 1). Alkaloids were not found in roasted fermented seeds. This absence of alkaloids has also been described by Nacoulma (1996) and Millogo/koné (2005).

\section{Acute Toxicity}

Reactive product acute toxicity study is of primary importance to determine their harmlessness for their use without risk of intoxication. The present study revealed that the minimal lethal dose would be higher than $3000 \mathrm{mg} / \mathrm{kg}$ of body weight. According to the scale of Hodge and Sterner, (1943) and OMS, (2002) these products would be classified practically without toxicity. This indicate high margin of safety in mice when administered orally. 
Table 1 Chemical groups characterized in the aqueous extract of $P$ biglobosa.

\begin{tabular}{lll}
\multicolumn{2}{l}{ Table 1 Chemical groups characterized in the aqueous extract of P biglobosa. } & Fermented Seeds \\
\hline Chemical groups & Roasted Seed & - \\
Alkaloids & - & - \\
Tanins & - & - \\
Saponosides & - & + \\
Triterpenes and stérols & + & - \\
Flavonosides & - & - \\
Coumarins & + & - \\
Anthraquinones & - & - \\
Anthocyanes & - &
\end{tabular}

+ Detected; - not detected.

Table 2: Acute toxicity of the aqueous extract from seeds of $P$. biglobosa in the mice (intra peritoneal way)

\begin{tabular}{lcccccc}
\hline Extract & $\mathrm{LD}_{99}(\mathrm{mg} / \mathrm{kg})$ & $\begin{array}{c}\mathrm{LD}_{50} \\
(\mathrm{mg} / \mathrm{kg})\end{array}$ & $\begin{array}{c}\mathrm{LD}_{1} \\
(\mathrm{mg} / \mathrm{kg})\end{array}$ & $\mathrm{LD}_{99} / \mathrm{LD}_{50}$ & $\mathrm{LD}_{50} / \mathrm{LD}_{1}$ & $\mathrm{LD}_{99} / \mathrm{LD}_{1}$ \\
FS & $4175 \pm 0725$ & $1800 \pm 0212$ & $775 \pm 096$ & 2.32 & 2.32 & 5.33 \\
RS & $5250 \pm 0814$ & $1600 \pm 0325$ & $487 \pm 053$ & 3.28 & 3.28 & 10.76 \\
\hline
\end{tabular}

FS: Fermented Seeds; RS: Roasted Seeds. $\mathrm{LD}_{99}, \mathrm{LD}_{50}$ and $\mathrm{LD}_{1}$ values expressed as mean \pm S.E.M.

Table 3: Values of $\mathrm{EC}_{50}$ and Maximal effect

\begin{tabular}{|c|c|c|c|}
\hline & & $\begin{array}{c}\mathrm{EC}_{50} \\
(\mathrm{mg} / \mathrm{mL})\end{array}$ & Maximal effect \\
\hline \multirow[t]{3}{*}{ Fermented seeds } & With endothelium & $5.37 \pm 0.12$ & 100 \\
\hline & Without endothelium & $4.19 \pm 1.02$ & 100 \\
\hline & With endothelium & $5.39 \pm 1.12$ & 100 \\
\hline Roasted seeds & Without endothelium & $5.93 \pm 0.95$ & 100 \\
\hline
\end{tabular}

$\overline{\text { Value expressed as mean } \pm \text { S.E.M. }}$

For intra peritoneal administration, the $\mathrm{LD}_{50}$ curves regression was validated by the equality of ratios $\mathrm{LD}_{99} / \mathrm{LD}_{50}$ and $\mathrm{LD}_{50} / \mathrm{LD}_{1}$. These ratios were 2.32 and 3.28 respectively for roasted and fermented seeds (Table 2). In this administration way, the $\mathrm{LD}_{50}$ of roasted and fermented seeds were $1800 \pm 212 \mathrm{mg} / \mathrm{kg}$ and $1600 \pm 325 \mathrm{mg} / \mathrm{kg}$ of body weight respectively (Table 2). According to the scale of Hodge and Sterner, (1943) and OMS, (2002) these products were classified lightly toxic. The index of safety given by ratio $\mathrm{LD}_{99} / \mathrm{LD}_{1}$ is 5.33 and 10.76 for roasted and fermented seeds respectively. The index of safety of fermented seeds used as condiment is higher than 10; thus indicating a good margin of safety of the product. For the two extracts, the animals die in the interval of $24 \mathrm{~h}$. It thus acts as an immediate toxicity. The toxidrom indicates a somnolence in the mice, which could be due to the sedative action of the terpenic chemical compounds contained in the extracts. Indeed, Anton, (1979) reported that the terpenic compounds were endowed with sedative properties. These same effects of monoterpen and triterpen are reported by Takashi, (2005).

\section{Study on Rat aorta.}

Stimulation of aorta rings by phenylephrine $10^{-6} \mathrm{M}$ induced a constant contraction (2.12 $\pm 0.15 \mathrm{~g}$; $\left.\mathrm{n}=8\right)$. Aqueous extract from fermented seeds cumulative addition produced a concentration-dependent relaxation on aorta with or without endothelium (Figure $1 \mathrm{~A}$ ). Figure 1B shows similar results with the aqueous extract from roasted seeds. This extract induced a relaxing effect on intact and endothelium-denuded aorta. For all extract contraction are totally inhibited. These results revealed similar values for Effective Concentrations $50\left(\mathrm{EC}_{50}\right)$ (see Table 3); indicating that effects are independent from the presence of endothelium. Nevertheless it is noticed that for the low concentrations $(1-4 \mathrm{mg} / \mathrm{mL})$ of roasted seeds, the vasorelaxant effect seems related partly to the presence of endothelium (Figures $1 \mathrm{~B}$; and 2).

Antihypertensive and hypotensive properties of fermented seeds of $P$. biglobosa were already reported by Assane et al., (1993). We show here that one of the possible mechanisms of this antihypertensive property would be by reduction of vascular resistances. Vasorelaxant effect of P. biglobosa have also been observed by Tokoudagba et al (2009; 2010) about 


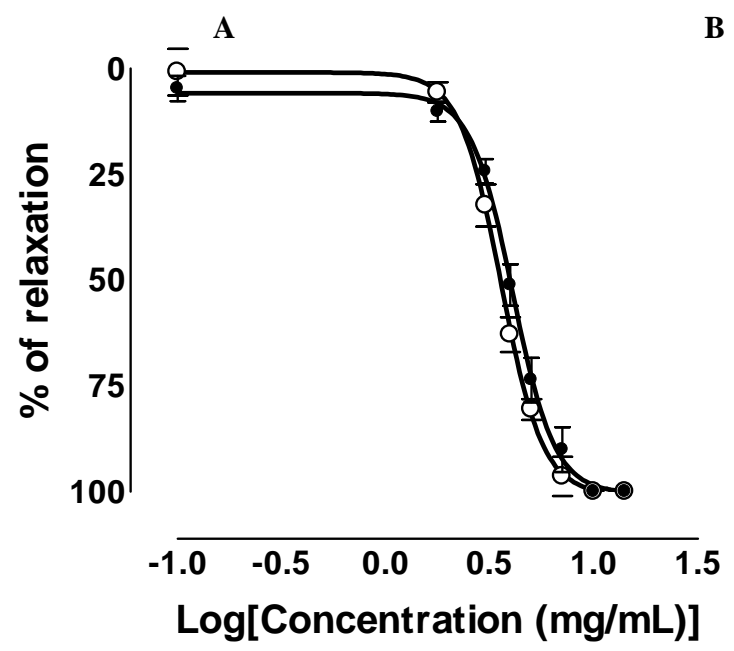

B

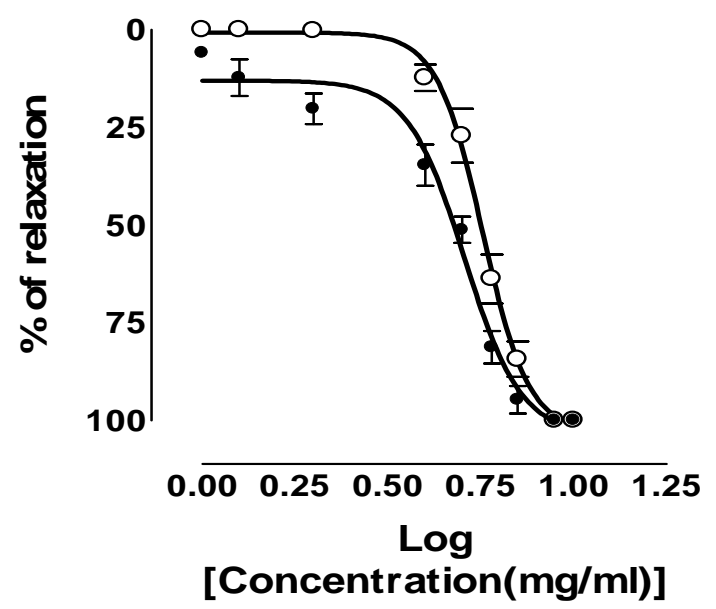

Figure 1: Cumulative concentration-response curves to aqueous extract from fermented (A) and roasted (B) seeds of $P$. biglobosa on isolated rat aorta, previously contracted with phenylephrine $\left(10^{-6} \mathrm{M}\right)$ in the presence or in the absence of endothelium (filled and open circles respectively). Each point represents the mean \pm S.E.M. of 5 to 6 rats.

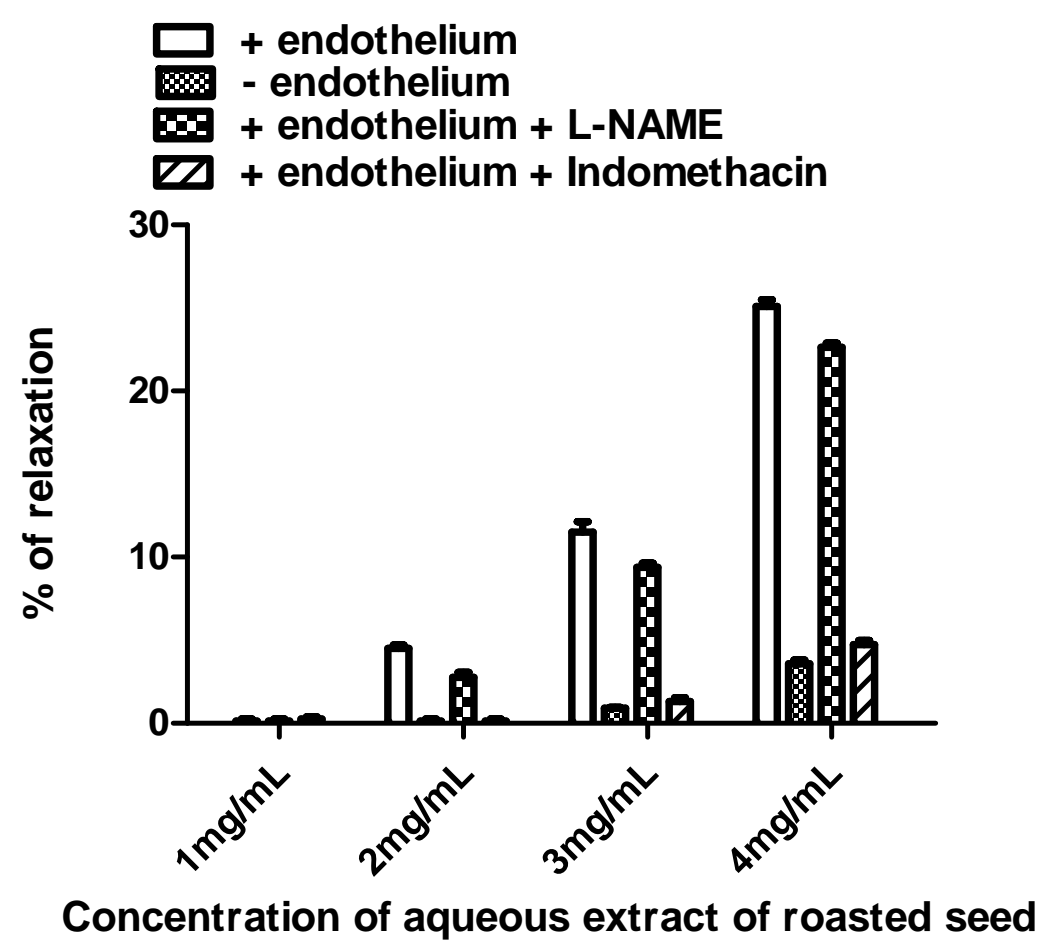

Figure 2: Effect of the L-NAME $\left(3 \times 10^{-4} \mathrm{M}\right)$ and the indomethacin $\left(10^{-5} \mathrm{M}\right)$ on relaxing effect in the presence of endothelium of the aqueous extract of roasted seed from P. biglobosa. Each bare represents the mean \pm S.E.M. of 5 to 6 rats.

leaves and raw seeds and by Kane et al (2009) about bark. We are not able at present, to link the observed activity to any of the constituents. Moreover phytochemical compounds can act alone or in synergy for a pharmacological effect (Donald, 2000). Neither flavonoids nor tanins have been detected in seeds. However, as described by Tokoudagba et al (2010), polyphenolics compounds are present in leaves and may contribute to vasorelaxation activity. Nevertheless, among the revealed chemical compounds in these present extracts, terpenic and steroidic one with some of their derivatives is endowed with an anti-hypertensive activity. Indeed the antihypertensive activity of the triterpenic compounds isolated from Zygophyllum coccineum L in the anaesthetized rat was reported by Gibbons (2001). In addition, Takashi (2005) indicated that the monoterpen and the triterpen were endowed with hypotensives properties.

For the low concentrations $(1-4 \mathrm{mg} / \mathrm{ml})$ of roasted seeds extract, the vasodilatory effect partly depends on endothelium (Figure 1B). It is well known that one of the most important mechanisms of regulation of vascular tonicity 
depends on Nitric Oxide (NO) and prostacyclin ( $\mathrm{PGI}_{2}$ ) (Furchgott and Zawadzki, 1980; Palmer et al., 1987; Moncada et al., 1988) from endothelium.

We thus examined $\mathrm{NO}$ and $\mathrm{COX}$ metabolites relative contribution in the relaxing effect by low concentrations of this extract. The pretreatment of the aorta in the presence of endothelium with the L-NAME $\left(3.10^{-4} \mathrm{M}\right)$ does not influence the vasorelaxant effect of the extract (Figure 2). However, Tokoudagba et al (2010) showed that endothelium vasorelaxant effect of leaves are reduced in presence of an inhibitor of NOS. On the other hand, the presence of the indomethacin $\left(10^{-5} \mathrm{M}\right)$ abolished the vasorelaxant effect of the extract. Inhibition by the indomethacin clearly indicates COX metabolites, probably $\mathrm{PGI}_{2}$ involvement in aorta relaxation process by this extract.

\section{Conclusion}

The present study made it possible to highlight by scientific tests, aqueous extracts from $P$. biglobosa roasted and fermented seeds chemical groups, and its vascular effect. Toxicity study indicates that these seeds used like food, are practically without danger by oral route. These results also enabled us to conclude that extracts induced a relaxing effect on the rat aorta. P. biglobosa seems to act directly on the smooth muscle and via endothelium involving the generation of vasodilatating prostaglandins. These arguments are in favour of its use in ethnomedicine for the treatment of arterial hypertension. These kinds of products may have also intense interest as nutraceuticals.

\section{Acknowledgement}

Our gratitude to the «Cooperation et Action Culturelle, Fond de Solidarité Prioritaire, Ambassade de France au Burkina Faso " for the financial support which made possible this work. We are grateful to Traditional healers of Ioba and Passoré provinces for their prompt collaboration. We are also grateful to International Foundation for Sciences (IFS) for financial support.

\section{References}

1. Andriambeloson, E., Kleschyov, A.L., Muller, B., Beretz, A., Stoclet, J.C. and Andriantsitohaina, R. (1997). Nitric oxide production and endothelium-dependent vasorelaxation induced by wine polyphenols in rat aorta. British Journal of Pharmacology. 120: 1053-1058.

2. $\quad$ Anton R. (1979). Médicaments aromatiques, une thérapeutique d'avenir ? Les accidents pharmaceutiques. $154: 26$.

3. Assane, M., Baba, M.R., Bassene, E. and Sere, A. (1993). Etude de l'action antihypertensive des graines de Parkia biglobosa (JACQ). BENTH chez le rat. Dakar médical. 38: 49-54.

4. Bertrand, E., Akinkugbe, O.O. and Frances, Y. (1995). Hypertension artérielle des populations originaire d’Afrique Noire. Edition Pradel, Paris. 125p.

5. Ciulei, I. (1982). Pratical manuals on the industrial utilization of chemical and aromatic plants- Methodology for analysis of vegetable drugs - Ed. Ministry of chemical industry, BUCHAREST, 67 p.

6. $\quad$ Cooper, R., Rotini, C., Ataman, S. and Osotimehin, B. (1997). The prevelance of hypertension in seven populations of West Africa origin. Am. J. Public Health. 87: 160-168.

7. Donald, P.B. (2000). Medicinal plants and phytomedicine. Linking plant biochemistry and physiology to human heath. Plant physiology. 124: 507-514.

8. Du Caillar, G., Ribstein, J., Halicini, J.M. and Mimran, A. (1995). Organes cibles de l'hypertension artérielle. Médecine et Hygiène. 53p.

9. Furchgott, R.F. and Zawadzki, J.V. (1980). The obligatory role of endothelial cells in the relaxation of arterial smooth muscle by acetylcholine. Nature. 299: 373-3376.

10. Gibbons, S. (2001). Antihypertension effect of an aqueous extract of Zygophyllum coccineum L. in rats. Phytother. Res. 15: 452-455.

11. Hodge, H.C. and Sterner, J.H. (1943). Determination of substance acute toxicity by LD50. American Industrial Hygien Association. 10: 93.

12. Kane, M.O., Sarr, M., Gueye, P.M., Ndiaye, C.A.B., Diaw, M., Ba, A., Sar, F.B., and Sall Diallo, A., (2009). Vascular relaxant effects of a hydroalcoholic extract of bark of Parkia biglobosa (Mimosaceae). ScienceLib 2.

13. Lichfield, J.F. and Wilcoxon, F.A. (1949). A simplified method of evaluation doses-effects experiments. J. Pharmacol. Exp. Ther. 95: 996-1113.

14. Miller, L.C. and Tainter, M.L. (1944). Estimation of $\mathrm{LD}_{50}$ and its error by log-probit grap paper. Pro. Soc. Biol. Exp. Med. 2944 (57): 261-264.

15. Millogo/Kone H. : (2005). Etude de la phytochimie et des activités biologiques d'extraits de Parkia biglobosa (Jacq.) Benth.-Thèse Doct- universite de Ouagadougou-169 pages.

16. Moncada, S., Radomski, M. K. and Palmer, R. M. J. (1988). Endothelium-derived relaxing factor : identification as nitric oxide and role in the control of vascular tone and platelet function. Biochem. Pharmacol. 37: 2495-2501.

17. Nacoulma/ Ouédraogo, O. G. (1996). Plantes médicinales et Pratiques médicales Traditionnelles au Burkina Faso : Cas du plateau central. Thèse Doct. d'Etat ès Sciences Nat- Université de Ouagadougou. Tome1 et 2, 242p et 285p.

18. Niakara, A., Nébié, L.V.A., Zagré, M.N., Ouédraogo, N.A. and Megnigbeto, A.C. (2003). Connaissance d'une population urbaine sur l'hypertension artérielle: Enquête prospective menée à Ouagadougou, Burkina Faso. Bull. Soc. Pathol. Exot. 96 (3): 219-222. 
19. Olatunbosun, S.T., Kaufman, J.S., Cooper, R.S., and Bella A.F. (2000). Hypertension in black population: prevalence and biosocial determinants of hight blood pressure in a group of urban Nigerias. J Hum Hypertens. 14: 249-257.

20. Organisation Mondiale de la Santé (2002). Bureau international du travail : Encyclopédie de sécurité et de santé au travail, édition BIT., volume II, Génève, 62.8-6244.

21. Palmer, R. M. J., Ferrige, A. G. and Moncada, S. (1987). Nitric Oxide release accounts for the biological activity of endothelium-derived relaxing factor. Nature 327: 524-526.

22. Pechere, B.A., Brunner, H.R. and Wacher, B. (1996). Investigations rénales chez le patient hypertendu. 54p.

23. Prieur, D.J., Young, D.M., Davis, R.D., Coney. Homan, E.R., Dixion, R.L. and Guarino, A.M. (1983). Procedures of preclinical toxicologic evaluation production. Journal of applied microbiology. 102 (4): 963-970.

24. Serme, D., Lengani, A. and Ouandaogo, B.J. (1991). Morbidité et mortalité cardiovasculaire dans un service interne de Ouagadougou- cardiologie tropicale. 17(65): 23-28.

25. Takashi, I. (2005). Biotransformation of terpenoïds by Mammals, Microorganisms, and Plant-Cultured cells. Chemestry and Biodiversity. 2: 569-590.

26. Tokoudagba, J.M., Augera, C., Bréant, L, N’Gom, S., Chabert, P., Idris-Khodja, N., Gbaguidi, F., Gbenou, J. Moudachirou, M., Lobstein, A. and Schini-Kerth, VB. (2010). Procyanidin-rich fractions from Parkia biglobosa (Mimosaceae) leaves cause redox-sensitive endothelium-dependent relaxation involving NO and EDHF in porcine coronary artery. Journal of Ethnopharmacology. 132: 246-250.

27. Tokoudagba, JM., Chabert, P., Auger, C., N’Gom, S., Gbenou, J., Moudachirou, M., Schini-Kerth, V. and Lobstein, A. (2009). Recherche de plantes à potentialités antihypertensives dans la biodiversité béninoise. Ethnopharmacologia, 44: 3249.

28. Tougma, S.J-B. (2002). Les complications cardiaques de l'hypertension artérielle de l'adulte au CHNSS : A propos de 293 cas. Thèse Doctorat Médecine N805, Université de Ouagadougou, Burkina Faso, 73p.

29. Trevan, J.W. (1927). The error of determination of toxicity. Proc. Royal. Soc. 101 B: 483-514.

30. Van Rooyen, J.M., Kruger, H.S., Huisman, H.W. Wissing, M.P. and Margetts, B.M. (2000). An epidemiological study of hypertension and it determinants in a population in transition: The THUSA study. J. Hum. Hypertens. 14: 779-787. 